\title{
Congruence between Sibling Relationship and Parenting Practices across
}

\section{Older and Younger Siblings}

\author{
Şule Selçuk' ${ }^{1}$ Berna Aytaç²
}

Selçuk, Ş., \& Aytaç, B. (2020). Congruence between sibling relationship and parenting practices across older and younger siblings. Nesne, 8(16), 16-30. DOI: 10.7816/nesne-08-16-02

\section{Keywords} Sibling relationship quality, parenting, older siblings, younger siblings

\begin{abstract}
This study aimed to investigate whether maternal control and discipline practices relate to perceived sibling relationship quality with the mediating role of perceived maternal warmth and hostility across younger and older siblings, and whether the pattern of relations differs across siblings. As previous studies examining the link between parenting and child-related outcomes generally recruited only one child in a family, we recruited two siblings growing in the same family to examine child-specific influences. A total of 100 Turkish families with older (5.3 - 8.7 years) and younger siblings ( $3-5.5$ years) participated in the study. Mothers reported their discipline practices, observers rated mothers' control practices, and siblings reported maternal warmth and hostility, and sibling positive affect and conflict. Results revealed that, for both siblings, higher maternal positive control was related to higher perceived maternal warmth, in turn, associated with higher perceived sibling positive affect, and higher maternal negative discipline was linked with higher perceived maternal hostility, in turn, related to higher perceived sibling conflict. Moreover, younger siblings whose mothers used higher positive control perceived their mothers as being less hostile yet there was no such association for older siblings. Overall, findings suggested that there is a congruence between parent-child relationship and sibling relationship quality across older and younger siblings.
\end{abstract}

\section{Kardeş İlişskileri ve Ebeveyn Uygulamaları: Büyük ve Küçük Kardeşler arasındaki Uyum}

$\ddot{O} z$

Anahtar kelimeler

Kardeş ilişkisinin

kalitesi, ana

babalık, büyük

kardeşler, küçük

kardeşler
Bu çalışmada aynı ailede yetişen büyük ve küçük kardeşlerde, annenin kontrol ve disiplin uygulamalarının, anneden algılanan sıcaklık ve düşmanlık aracılığı ile algılanan kardeş ilişkisi ile bağlantılı olup olmadığı ve sözü edilen bu ilişki örüntüsünün kardeşler arasında farklılaşıp farklılaşmadığı incelenmiştir. Ana babalık ile çocuğa ilişkin sonuçlar arasındaki ilişkiyi araştıran önceki araştırmalar genel olarak, sadece tek bir çocuk ile yürütülmüștür; ancak bu çalışmaya çocuğa-özgü etkileri de incelemek amacıyla aynı aileden iki kardeş dahil edilmiştir. Büyük (5.3 - 8.7 yaş) ve küçük çocuğu ( 3 - 5.5 yaş) olan toplamda 100 aileye ulaşılmıştır. Anneler kendi disiplin uygulamalarını, gözlemciler annelerin kontrol uygulamalarını, kardeşler de annelerinden algıladıkları sıcaklık ve düşmanlığın yanı sıra kardeşleriyle ilişkilerinde algıladıkları olumlu duyguları ve çatışmayı rapor etmişlerdir. Sonuçlar her iki kardeşte de annenin pozitif kontrolü arttıkça, anneden algılanan sıcaklığın arttığını ve buna bağlı olarak kardeş ilişkisinde algılanan olumlu duygunun yükseldiğini, annenin negatif disiplin uygulamaları arttıkça ise anneden algılanan düşmanlığın arttığını ve buna bağlı olarak algılanan kardeş çatışmasının yükseldiğini göstermiş̧tir. Bunlara ek olarak, anneleri daha fazla pozitif kontrol kullanan küçük kardeşlerin annelerini daha az düşmanca algıladıkları ancak büyük kardeşlerde bu yönde bir örüntü olmadığı görülmüştür. Özetle, elde edilen bulgular, hem büyük hem de küçük kardeşlerde ebeveyn-çocuk ilişkisi ile kardeş iliş̧isi arasında bir uyum olduğuna işaret etmektedir.

\footnotetext{
${ }^{1}$ Research Asisstant, PhD., Kastamonu University, Department of Psychology, sselcuk(at)kastamonu.edu.tr, ORCID: 0000-0003-0933-8174
} ${ }^{2}$ Asisstent of Professor, Hacettepe University, Department of Psychology, b.aytac(at)hacettepe.edu.tr, ORCID: 0000-0002-3565-3269 
According to Family System Theory, family is a complex system composing of different interdependent subsystems such as sibling, parent-child, and parent subsystem; and, there is a mutual relationship among these subsystems (Minuchin, 1985). However, there is a scarcity of research investigating the association between parenting and sibling relationship quality (Yu \& Gamble, 2008). Although available research suggests that parenting practices are linked with sibling relationship quality (e.g., Brody, Stoneman, \& MacKinnon, 1986; Gamble \& Yu, 2014; Jenkins, Rasbash, Leckie, Gass, \& Dunn, 2012; MacKinnon-Lewis, Starnes, Volling, \& Johnson, 1997; Relva, Alarcão, Fernandes, Carvalho, \& Fauchier, 2019; Yu \& Gamble, 2008), there is still so much more to learn about the mechanisms that can account this association. At this point, it should be noted that detecting the determinants along with the mechanisms through which they affect sibling relationship quality is important as both cross-sectional and longitudinal studies have demonstrated that the quality of sibling relationship is associated with children's psychological adjustment (e.g., Buist, Deković, \& Prinzie, 2013; Dirks, Persram, Recchia, \& Howe, 2015; Garcia, Shaw, Winslow, \& Yaggi, 2000; Pike, Coldwell, \& Dunn, 2005; Richmond, Stocker, \& Rienks, 2005). For instance, sibling relationship quality was found to be linked with siblings' internalizing and externalizing problems, and prosocial behaviors even when the parent-child relationship quality was controlled (Buist et al., 2013; Pike et al., 2005).

There are two competing hypotheses that have been proposed to account the association between the parent-child relationship and sibling relationship. Congruence hypothesis suggests a similar association between the quality of parent-child relationship and sibling relationship quality; whereas compensation hypothesis proposes an inverse association (see Boer, Goedhart, \& Treffers, 1992). However, as Derkman, Engels, Kuntsche, van der Vorst, and Scholte (2011) indicated, majority of related research supports congruence hypothesis. For instance, both cross-sectional and longitudinal studies conducted with adolescents indicated that the relationship between siblings whose mothers and/or fathers are supportive and democratic is more likely to be warm, supportive, and less conflictual (Buist et al., 2017; Cui, Conger, Bryant, \& Elder, 2002; Derkman et al., 2011; Gamble \& Yu, 2014). Similarly, a cross-sectional study revealed that both higher maternal and paternal warmth are linked with higher intimacy in adolescent sibling relationship (McHale, Updegraff, Tucker, \& Crouter, 2000). Another cross-sectional study conducted with boys, their siblings, and their mothers indicated that boys whose mothers are more rejecting are more likely to act aggressively in their sibling interaction (MacKinnon-Lewis et al., 1997). In line with these findings, Jenkins and colleagues (2012) found that expressed maternal negativity (i.e., hostility and conflict) and positivity (i.e., affection, engagement, rule explanation, and compromise) influence sibling relationship in the expected directions. Overall, these findings imply that both positive and negative practices of parents are associated with or reflect on sibling relationship. Therefore, we aimed to investigate whether observed maternal control and mother-reported discipline practices relate to perceived sibling relationship quality (i.e., sibling positive affect and sibling conflict) with the mediating role of perceived maternal warmth and hostility across older and younger siblings.

Based on aforementioned findings, we included both positive and negative discipline and control practices of mothers in order to reveal their joint and unique association with sibling relationship via their link with perceived maternal warmth and hostility. Positive control and discipline practices are defined as directive behaviors such as praising the child's behavior, use of rewards and explanations, and being firm 
and calm whereas negative control and discipline practices refer to power-assertive behaviors such as use of criticism, physical control, shouting, and smacking (Deater-Deckard, 2000).

The vast majority of previous research investigating the influence of parenting on child-related outcomes has relied on one child per family. The implicit assumption made is that parenting and its effects are similar across all children within families (Dunn \& Plomin, 1990). In fact, children in the same family can be different from one another, which has led some researchers to examine child-specific influences (Plomin, Asbury, \& Dunn, 2001). Siblings' experiences and/or perceptions of the same experiences may differ to a great extent even if they are raised in the same family (Daniels \& Plomin, 1985; Deater-Deckard, 2000). Therefore, it is rather essential to evaluate at least two siblings in each family to gain a clear understanding regarding siblings' differential perceptions of certain experiences (i.e., parenting and sibling relationship). Thus, in the present study, we included siblings growing up in the same family during childhood and explored whether there are differences in the pattern of relations.

There may be differences in the suggested relationships across siblings for the following reasons. First, it is known that parents are supposed to play variant roles and exert different behaviors in response to diverse developmental tasks which children need to accomplish across life span (Herbert, 2004). For instance, parents were found to use more discipline to older (preschool) siblings compared to younger (toddler) siblings (Volling \& Ellins, 1998). In Turkish context, mothers are also more likely to exert higher negative control and discipline practices to older children compared to younger children since these practices are commonly used to provide guidance for children (see Aytac, Pike, \& Bond, 2019; Kağıtçıbaş1, 1989). Secondly, in addition to actual experiences, siblings may also differ in terms of how they perceive their mother's parenting behaviors (see Dunn, Plomin, \& Daniels, 1986; Sputa \& Paulson, 1995). The reason for differential treatment or distinct perceptions of siblings may result from a number of factors such as genetic differences, gender, birth-order, temperamental differences, different communicative skills, and different needs (Brody, Stoneman, \& McCoy, 1992; Dunn et al., 1986; Sputa \& Paulson, 1995).

As siblings may attribute different meanings to their mothers' control and discipline practices, the association of these practices with perceived sibling relationship would be different across siblings. The age of the sibling may be an important factor creating a difference in the interpretations of parental discipline and control practices. This may partly result from different cognitive abilities at different ages. Especially the ages of five to seven are defined as the ages of dramatic improvement in cognitive abilities (Sameroff $\&$ Haith, 1996). Moreover, since older siblings show higher involvement in activities involving other children and adults (see Sameroff \& Haith, 1996), they may have more opportunity to evaluate whether their parents' behaviors are common or rare in their surroundings compared to their younger siblings. At this point, it should be noted that cultural context is an important factor that shape parenting practices and the meanings attached to these practices (Bornstein, 2012). For instance, Aytac et al. (2019) demonstrated that hostility is the most prominent feature of parenting for English mothers whereas warmth is the defining aspect of parenting among Turkish mothers. This finding suggests that some negative parenting behaviors such as criticism may be more likely to be evaluated by children as a sign of care and interest in Turkish context (Aytac et al., 2019). Taken together, the normativity of specific parental behaviors may be more likely to influence older sibling's evaluations about these practices compared to younger siblings. For instance, younger children might attribute negative meanings to negative control and discipline practices whereas older children may tend to evaluate these practices as a sign of caring and protection rather than hostility. In 
addition, as parents may behave differently to older and younger siblings and also the expectations of older and younger siblings from their interactions with siblings may differ, the pattern/strength of the relations among study variables would differ. Accordingly, the mediating role of perceived maternal warmth and hostility in the association of observed maternal control and mother-reported discipline practices with perceived sibling relationship quality may vary across older and younger siblings.

In developmental research, the appropriateness of employing parent report data is criticised among some scholars because of some disadvantages such as parents' being biased in their reports and lack of normative criteria among parents creating a reliability problem (Seifer, 2005). The strongest alternative to parent report is to use trained observers to collect data but this method has also its own disadvantages (e.g., observing the behavior in a limited time and setting) (see Seifer, 2005). In many studies, mothers are the only reporters providing information about their children, themselves, and/or their relationships. The associations revealed in such studies may be the function of employing common reporter rather than true relationships among evaluated constructs (see Podsakoff, MacKenzie, Lee, \& Podsakoff, 2003). To overcome these problems, we collected data from multiple sources (i.e., mothers, observers, and children). Both mothers and observers provided information regarding parenting practices so as to see possible differential relationships for mother-reported and observer-coded data (even they rated similar constructs, i.e., observers coded maternal control and mothers reported parental discipline), and to interpret the results more accurately.

Taken together, the present study aimed to explore the association between parenting practices and children's perceived sibling relationship quality with the mediating role of children's perception of parenting quality across younger and older siblings in Turkish context. We hypothesized that maternal control and discipline practices would be related to sibling relationship quality (i.e., sibling positive affect and sibling conflict) via perceived maternal warmth and hostility (Hypothesis 1). In addition, we hypothesized that the pattern of relations would differ across older and younger siblings (Hypothesis 2). More specifically, we expected that the positive association of maternal negative control and discipline practices with perceived maternal hostility would be weaker for older children compared to younger children due to developmental differences between older and younger siblings that mentioned earlier. However, for other relations, we did not have prior assumptions regarding in what ways older and younger children may differ due to scarcity of related research which would direct our assumptions. Therefore, in this respect, this study was explanatory in nature to a great extent in terms of sibling differences in Turkish context.

\section{Method}

\section{Participants}

The current study uses data collected from 100 Turkish families in 2010 (see Aytac, 2013). The average age of the older siblings was 8.1 years $(S D=9.88$ months), and the average age of the younger sibling was 4.7 years $(S D=9.41$ months). Families were two-parent intact families and the average family size was $4.45(S D=.91)$ (67\% of the families consist of mother, father, and two children). There were 17 brother-brother, 27 sister-sister, 29 older sister- younger brother, and 27 older brother-younger sister sibling dyads. The sample was homogenous in terms of age spacing $(M=2.92, S D=.65)$. The older siblings were not necessarily the oldest, and the younger siblings were not necessarily the youngest in their families. Current study investigates sibling pairs in early to middle childhood. Most of children's exchanges with 
others during early childhood occur in their families and their social networks expand significantly during middle childhood. By the ages 10 to 12 years, children become more involved in peer relations (Collins, Madsen, \& Susman-Stillman, 2002). The older siblings in the sample were not yet 9 years old. This aims to capture family relationships still characterized by high intensity and emotionality, before the pulls from outside the family that can serve to weaken the warmth and intimacy of the bonds had taken hold (Dunn, 2002).

The sample comprised ordinary families drawn from the local community rather than families facing particular difficulties. Families came from a mix of working-class and middle-class backgrounds. $30 \%$ of mothers and $16 \%$ of fathers had left school by age $16.40 \%$ of mothers and $46 \%$ of fathers continued academic education until age 18 . The remaining mothers $(30 \%)$ and fathers $(38 \%)$ finished vocational training, or completed either undergraduate or post graduate degrees.

\section{Recruitment and Procedure}

This study has been approved by the ethics committee at University of Sussex. Families were recruited through information leaflets distributed to parents at nursery and primary schools, as well as via online family websites, mailing groups, and recommendations made by families participating in the study in Central Anatolia area. We acknowledge that the sample is representative of only part of the Turkey. One or two researchers conducted home visits which began by gaining informed consent by mothers and verbal consent by children. These visits lasted 1.5-2 hours. Mothers and children were interviewed separately, and mothers completed questionnaires. Also, mothers and each child in turn were videotaped while completing a structured task, which is the Etch-a-Sketch. Families have been given a CD that recorded their interactions.

\section{Measures}

Questionnaires were translated into Turkish by two researchers independently, then they met to agree on the translation. This was then back-translated into English by a third translator. The translation revised once again, and the questionnaires were piloted with five mothers to check for clarity. This resulted in a few additional minor modifications to the final Turkish version of materials (see Aytac, 2013).

Etch-a-sketch Task (Deater-Deckard, 2000): The mother and children were observed using an Etch-A-Sketch drawing toy which has two dials; one for drawing vertically and the other for drawing horizontally. The mother and one of her children were assigned a dial, and told not to use each other's dial so that they had to cooperate to complete the task. They were asked to draw a rectangle with across through it and then a more complex drawing of a house. Each mother-child dyad from the videotaped interactions was rated by using the Parent-Child Interaction System or PARCHISY (Deater-Deckard, 2000; Deater-Deckard, Pylas, \& Petrill, 1997). Observers completed two 7-point Likert-type scales $(1=$ none, 7 = exclusive use of/constantly) from the PARCHISY: positive control (i.e., the use of praise, explanation and open ended questions); negative control (i.e., the use of criticism and physical control of the child). In order to test inter-rater reliability, a second researcher coded $40 \%$ of the videos independently. Interrater reliability of the original task was .86 for positive control and .95 for negative control (Deater-Deckard, 2000). In the present study, correlations between the two coders were reasonable, .70 for positive control and .81 for negative control.

Parental Discipline (Deater-Deckard, 2000): This 6-item questionnaire asks parents to rate how often they used various methods of discipline with their children. These were rated on a 5-point scale ranging from 1 (never) to 5 (usually). Two subscales were derived: Positive Discipline (e.g., "be firm and calm with child") 
and Negative Discipline (e.g., "give a smack or slap"). In the original interview form (Deater-Deckard, 2000 ), the interrater reliability was reported to be above .88 . In the questionnaire form, Cronbach's alphas ranged from .52 to .58 (Pike et al., 2005). In the present study, for positive discipline, the Cronbach's alpha was .86 for older siblings and .74 for younger siblings; and for negative discipline, the Cronbach's alpha was .47 for both siblings. These internal reliabilities were reasonable taking into account the small number of items, and the effect that this has on alpha values (see Field, 2009).

Berkeley Puppet Interview (BPI) (Ablow \& Measelle, 1993): The 12-item and 14-item interviews aim to obtain reports from young children about their relationship with their mothers and siblings, respectively. During the audio-taped interview, two identical puppets make opposing statements about their mothers (e.g., 'My mum is nice to me' 'My mum is not nice to me') or their siblings (e.g., 'I like having a sibling' 'I don't like having a sibling') then ask the child about themselves (e.g., 'How about your mum/sibling?'). The researcher covers her face with the puppets in order to encourage the child to interact directly with the puppets. Two subscales assess children's relationships with their mothers; one is 6-item warmth ("My mum hugs and kisses me", "Me and my mum have fun together") and the other is 6-item hostility ("My mum is mean to me", "My mum shouts at me when she is cross"). When a child chooses a response option as expressed by the puppet, a code 2 (for a negative response - 'my mum is not nice to me') or a code 6 (for a positive response - 'my mum is nice to me too') is used. When a child amplifies a statement (e.g., 'my mum is horrible to me' or 'my mum is really nice to me'), a code 1 (negative) or 7 (positive) is used. A code 3 or 5 indicates a response that is qualified in some way (e.g., 'my mum isn't nice to me most of the time' or 'My mum is nice to me most of the time'). Finally, a code 4 is used when a child indicates that both response options apply to them. Pike and colleagues (2005) confirmed that warmth and hostility are distinct subscales and Cronbach's alpha values were found to range between .65 and .67 for maternal warmth, and .62 and .74 for maternal hostility. For the present study, internal consistencies for warmth and hostility subscales were .53 and .68 for older siblings, respectively. The corresponding values were .54 and .66 for younger siblings. A similar coding procedure was followed to calculate sibling positive affect and sibling conflict from their corresponding subscales (i.e., 6-item sibling positive affect and 8-item sibling conflict). Internal consistencies were found to be .88 for sibling positive affect and .79 for sibling conflict for the original interview (see Measelle, Ablow, Cowan, \& Cowan, 1998). In the present study, internal consistencies for sibling positive affect and sibling conflict subscales were .71 and .68 for older siblings and .65 and .56 for younger siblings, respectively.

\section{Preliminary Analyses}

\section{Results}

As preliminary analyses, descriptive statistics and zero-order bivariate correlations among study variables were calculated, and univariate ANOVAs were conducted (see Table $1 \&$ Table 2). As seen in the Table 1, the pattern of correlations among study variables were similar across siblings. For instance, for both siblings, maternal warmth was correlated positively with sibling positive affect and negatively with sibling conflict whereas maternal hostility was correlated negatively with sibling positive affect and positively with sibling conflict. However, there were also some differences between older and your siblings. For instance, the relationships of maternal positive control with maternal hostility, sibling positive affect, and sibling conflict were significant only for younger siblings. Whereas, the relationships of maternal positive control with maternal negative control, maternal negative discipline, and maternal warmth were significant only for older children. Moreover, as seen in Table 2, univariate ANOVAs revealed that older siblings scored higher on 
perceived maternal warmth and sibling positive affect than younger siblings. In order to see whether sex constellation of sibling dyads needs to be controlled in the main analyses, we conducted additional univariate ANOVAs. Results revealed that only maternal positive discipline differed as a function of sex constellation, $F(3,96)=4.61, p<.01$. Bonferroni pairwise comparisons indicated that mothers who have sister-sister $(M=$ $3.89, S D=.72)$ or older sister-younger brother children dyads $(M=3.89, S D=.86)$ reported more positive discipline compared to those who have brother-brother children dyads $(M=3.15, S D=1.08)$. Since there was no corresponding difference for the remaining study variables, we did not include sex constellation as a control variable in further analyses.

Table 1

Zero-order Bivariate Correlations of the Study Variables

\begin{tabular}{lcccccccc}
\hline & 1 & 2 & 3 & 4 & 5 & 6 & 7 \\
\hline 1. Positive Control & - & $-.260^{*}$ & $.291^{* *}$ & $-.231^{*}$ & $.217^{*}$ & .006 & -.009 & -.074 \\
2. Negative Control & -.108 & - & -.128 & .022 & -.188 & .153 & -.195 & .075 \\
3. Positive Discipline & $.292^{* *}$ & -.059 & - & $-.454^{* *}$ & .038 & -.12 & .104 & .003 \\
4. Negative Discipline & -.168 & -.137 & $-.274 * *$ & - & -.124 & $.217^{*}$ & -.154 & .194 \\
5. Maternal Warmth & .198 & $-.238^{*}$ & -.004 & -.069 & - & $-.389^{* *}$ & $.491^{* *}$ & $-.257^{*}$ \\
6. Maternal Hostility & $-.282^{* *}$ & -.001 & -.060 & $.348^{* *}$ & $-.281^{* *}$ & - & $-.298^{* *}$ & $.441^{* *}$ \\
7. Sibling Pos. Aff. & $.252^{*}$ & -.090 & $.243^{*}$ & -.198 & $.489 * *$ & $-.320^{* *}$ & - & $-.426^{* *}$ \\
8. Sibling Conflict & $-.223^{*}$ & .186 & $-.255^{*}$ & .235 & $-.295^{* *}$ & $.339^{* *}$ & $-.404^{* *}$ & - \\
\hline
\end{tabular}

$* p<.05, * * p<.01$.

Note. Sibling Pos. Aff. $=$ Sibling Positive Affect

The values above the diagonal are for older siblings; the values below the diagonal are for younger siblings

Table 2

Descriptive Statistics of the Study Variables and Group Difference Tests

\begin{tabular}{|c|c|c|c|c|c|c|c|c|}
\hline & \multicolumn{4}{|c|}{ Sibling } & \multirow{2}{*}{\multicolumn{2}{|c|}{ All }} & \multirow[b]{3}{*}{$F$} & \multirow[b]{3}{*}{$\eta_{p}^{2}$} \\
\hline & \multicolumn{2}{|c|}{$\begin{array}{c}\text { Older } \\
(n=100)\end{array}$} & \multicolumn{2}{|c|}{$\begin{array}{l}\text { Younger } \\
(n=100)\end{array}$} & & & & \\
\hline & Mean & $S D$ & Mean & $S D$ & Mean & $S D$ & & \\
\hline Positive Control & 2.77 & 1.18 & 2.71 & 1.09 & 2.74 & 1.14 & 0.11 & .001 \\
\hline Negative Control & 1.72 & 0.98 & 1.84 & 1.11 & 1.78 & 1.04 & 0.54 & .003 \\
\hline Positive Discipline & 3.50 & 1.08 & 3.70 & .97 & 3.60 & 1.03 & 1.72 & .009 \\
\hline Negative Discipline & 3.06 & .64 & 2.93 & .67 & 3.00 & .66 & 2.20 & .011 \\
\hline Maternal Warmth & 5.68 & .53 & 5.33 & .71 & 5.51 & .65 & $14.49 * *$ & .071 \\
\hline Maternal Hostility & 3.00 & .86 & 3.16 & .94 & 3.08 & .90 & 1.51 & .008 \\
\hline Sibling Positive Affect & 5.74 & .68 & 5.32 & .86 & 5.54 & .80 & $13.82 * *$ & .068 \\
\hline Sibling Conflict & 3.31 & .82 & 3.10 & .94 & 3.21 & .88 & 2.80 & .015 \\
\hline
\end{tabular}

$* * p<.001$. 


\section{Main Analyses}

We conducted main analyses with lavaan package (Rosseel, 2012) of R software (R Core Team, 2016). We first conducted separate path analyses for older and younger siblings in order to see whether maternal control and discipline practices relate to perceived sibling positive affect and sibling conflict through their associations with maternal warmth and hostility. Then, we performed multiple group path analysis in order to explore whether these associations differ across older and younger siblings. In these analyses, we used full information maximum likelihood (FIML) to predict missing values in the data. However, in total, 5 cases (i.e., 2 cases from older children and 3 cases from younger children) were removed by lavaan due to missing values in the exogenous variables. In addition, as it is robust to nonnormality in the data, we used maximum likelihood estimation with robust standard errors (MLR) to calculate parameter estimates. We also used the Satorra-Bentler scaled chi square difference test (Satorra \& Bentler, 2001) to compare our nested models. Due to shared method variance, all models included correlated error terms between perceived maternal warmth and maternal hostility and between perceived sibling positive affect and sibling conflict.

Results of the path analyses indicated that for both older and younger siblings, full mediation model provided adequate fit to the data, for older children: $\mathrm{S}-\mathrm{B} \chi 2(8 ; N=98)=9.47, p>.10, \mathrm{CFI}=.98, \mathrm{SRMR}=$ .03 , RMSEA $=.04(90-\mathrm{CI}: .00-.13)$, and for younger children: $\mathrm{S}-\mathrm{B} \chi 2(8 ; N=97)=13.85, p>.10$, CFI $=$ $.92, \mathrm{SRMR}=.06, \mathrm{RMSEA}=.09$ (90-CI: $.00-.16)$. We explored if adding direct paths improve the fit of the model to the data. The chi-square difference between the model including both direct and indirect effects (i.e., partial mediation model) and the model specifying only indirect effects (i.e., full mediation model) was not significant, $\Delta \mathrm{S}-\mathrm{B} \chi 2(8)=9.18$ for older siblings, and $\Delta \mathrm{S}-\mathrm{B} \chi 2(8)=14.10$ for younger siblings, $p \mathrm{~s}>.05$. Therefore, we preferred the more parsimonious model that is full mediation model. It was revealed that the links between (1) observed positive control and perceived maternal warmth, (2) mother-reported negative discipline and perceived maternal hostility, (3) perceived maternal warmth and perceived sibling positive affect, (4) perceived maternal hostility and perceived sibling conflict were significant for both older and younger siblings. In addition, the associations between (1) observed negative control and perceived maternal hostility, (2) mother-reported positive discipline and perceived maternal warmth, (3) mother-reported positive discipline and perceived maternal hostility, (4) mother-reported negative discipline and perceived maternal warmth, and (5) perceived maternal hostility and perceived sibling positive affect were not significant for both older and younger siblings. Overall, it was revealed that maternal positive control was related to perceived maternal warmth, which in turn, was linked with perceived sibling positive affect, and maternal negative discipline was associated with perceived maternal hostility, which in turn, was related to perceived sibling conflict. In addition, perceived maternal hostility mediated the relationship between maternal positive control and sibling conflict only for younger siblings. Taken together, we partially confirmed our first hypothesis.

In addition, in order to explore whether regression paths significantly differ between older and younger siblings, we performed measurement invariance test. First, we tested the unconstrained (i.e., baseline) model. This model yielded adequate fit to the data: $\mathrm{S}-\mathrm{B} \chi 2(16 ; N=195)=23.40, p>.10, \mathrm{CFI}=$ $.95, \mathrm{SRMR}=.05, \mathrm{RMSEA}=.07(90-\mathrm{CI}$ : $.00-.13)$. Second, after constraining path coefficients to be equal for older and younger siblings, we released equality constraints one by one and re-estimated the model each time. As a result, we found that all but one path did not differ between older and younger siblings. More specifically, the association between maternal positive control and maternal hostility significantly differed 
between older and younger siblings, $\Delta \mathrm{S}-\mathrm{B} \chi 2(1)=4.92, p<.05$. It was revealed that for younger siblings, maternal positive control was significantly related to maternal hostility (Est. $=-.27, p<.01$ ) but there was no such link for older siblings (Est. $=.09, p>.10$ ) (see Figure 1). Although the association between maternal negative control and maternal warmth and the link between maternal warmth and sibling conflict were found to be significant only for younger siblings (see Figure 1), related path coefficients did not differ between older and younger siblings. Therefore, we partially confirmed our second hypothesis.

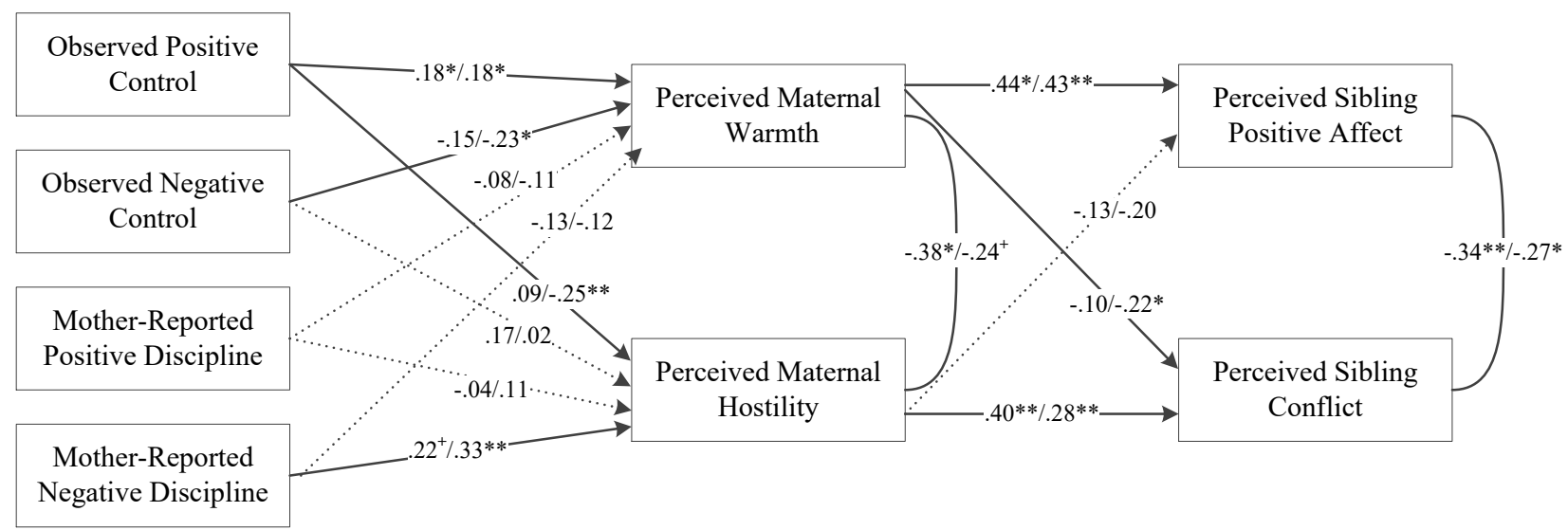

Figure 1. Path model showing the mediating role of perceived maternal warmth and hositility between the relationship of maternal control and discipline practices with sibling relationship quality

Note. ${ }^{+} p<.08,{ }^{*} p<.05,{ }^{* *} p<.01$. First and second values pertain older siblings and younger siblings, respectively.

\section{Discussion}

The current study aimed to investigate the association between parenting and sibling relationship quality with the mediating role of perceived maternal warmth and hostility across older and younger siblings. In addition, we aimed to contribute to growing research on sibling relationship by improving our understanding regarding the differences across younger and older siblings in the suggested links. As noted by Furman and Lanthier (2002), the relationship between siblings should not be deemed as "just one relationship" given that each sibling has its own perspective regarding their interactions and experience with their siblings. Moreover, it goes without saying that parents may behave differently to their children especially when they differ in age. Thereby, we recruited two siblings and their mother for each family. We used a combination of self-report, parent-report, and observation report to minimize shared method variance.

Findings based on correlations and mean comparisons indicated that the relationships among study variables and mean scores were similar across older and younger siblings to a great extent although there were some differences between siblings. For instance, maternal positive control was found to be negatively related to maternal hostility only for younger siblings. This finding was supported in the main analyses as the multigroup path analysis results indicated that mothers who use higher positive control are perceived as being less hostile only by younger siblings. In addition, it was shown that older siblings perceived higher maternal warmth and higher sibling positive affect compared to younger siblings. Despite these differences, the main analyses revealed that the pattern of relations was similar across older and younger siblings except 
one link mentioned earlier. For both siblings, it was shown that mothers who use higher positive control are perceived as being warmer whereas those who apply higher negative discipline are evaluated as being more hostile. In addition, it was shown that both older and younger siblings who perceive higher maternal warmth are more likely to have positive affect in their sibling interaction whereas those who perceive higher maternal hostility are more likely to have conflicts with their siblings.

First of all, current findings imply that parenting practices reflect on sibling relationship. This implication is line with the family system perspective proposing that family subsystems (e.g., parent, parentchild, and siblings) mutually influence each other hence, behaviors of an individual member of the family system may influence other individuals or subsystems (Minuchin, 1985). This finding is also consistent with previous findings confirming congruence hypothesis by showing that negative parenting impairs sibling relationship quality (see Brody 1998; Jenkins et al., 2012; MacKinnon-Lewis et al., 1997; Relva et al., 2019) whereas positive parenting improves the interaction among siblings (see Chen, 2018; Cui et al., 2002; Gamble \& Yu, 2014; McHale et al., 2000; Portner \& Riggs, 2016). Therefore, based on current and previous findings, it may be argued that the way parents discipline their child has an implication on how siblings interact with each other.

Moreover, findings indicate the importance of children's interpretations of parental behaviors as a mechanism through which parental control and discipline practices are linked with sibling relationship. The findings suggest that both older and younger children tend to appraise their mothers' positive control practices as a sign of parental warmth, and this reflects positively on the relationship with their siblings (i.e., feeling more positive affect in the interactions with siblings). In addition, it seems that if children interpret their mothers' negative discipline practices as an indication of hostility, then they are more likely to experience conflict with their siblings. Similar to this finding, previous research demonstrated that parents' physical and harsh verbal discipline or physical punishment are related to children's adjustment via children's perceptions of maternal hostility or perceived rejection by parents (Lansford et al., 2010; Rohner, Bourque, \& Elordi, 1996; Rohner, Kean, \& Cournoyer, 1991). Therefore, as Rohner (1986) pointed it out, our study along with previous studies indicate that it is quite crucial to take children's own perceptions (i.e., the meaning that the child attributes to these practices) while exploring the association of parental practices with child outcomes. It seems that children actively interpret their parents' practices and these interpretations shape their interactions with siblings.

The differences across older and younger siblings, although they are limited in number, may also reflect important implications. First, it was shown that older siblings reported higher maternal warmth compared to younger siblings. This difference among older and younger siblings may result from actual differential treatment of mothers in terms of maternal supportive behaviors. Alternatively, older children might be more likely to interpret the interview with the puppets as a public situation, where showing respect for parents is paramount. The reason for this is that respect is one of the social norms in Turkey where children are taught to honor their parents and not to say negative things about them. Secondly, the current study also revealed that older children are more likely to report higher sibling positive affect than younger siblings suggesting that social desirability may explain both of these differences. Indeed, a study conducted with preschool children indicated that social desirability bias increases with age (Ford \& Rubin, 1970). Moreover, another study conducted with elementary school children showed that children with higher social desirability scores are more likely to report family relationships in a positive light (Camerini \& Schulz, 2018). Therefore, it seems that older children are more likely to depict themselves and their family in a 
socially desirable way compared to younger children.

More importantly, older and younger siblings differed in terms of the association between maternal positive control and perceived maternal hostility. It was indicated that younger siblings perceive their mothers as being less hostile when their mothers show higher positive control, in turn they feel more positive affect in their interactions with their siblings but there was no such link for older siblings. It may be that younger siblings' perception regarding maternal hostility towards themselves might be more strongly associated with their mother's overt positive control practices such as praising and providing explanation. On the other hand, older children's corresponding evaluations may be primarily based on extremely harsh and punitive parenting behaviours such as physical punishment. In other words, positive control practices may lead older children to evaluate their mothers as being warmer but they might evaluate their mothers as being less or more hostile primarily depending on the level of their exposure to extremely negative parenting practices. Overall, as Grych and Finchman (1990) indicated earlier, this finding suggests that we should take into account children's developmental level when we evaluate children's perceptions. In addition, this finding also demonstrates that the mechanism between particular parenting practices and sibling relationship quality may be different for siblings.

Taken together, differential pattern of relationships among study variables across younger and older siblings was partially confirmed. It is known that the quality of sibling relationship tends to change due to developmental changes along with other types of relationship within the family (e.g., parent-child relationship) (Buhrmester, 1992). It was indicated that the nature of sibling and parent-child relationship change as a function of age-spacing between siblings (Furman \& Buhrmester, 1985; Kidwell, 1981). For instance, Buhrmester (1992) revealed that older and younger siblings differ in their perceptions regarding sibling conflict and this difference widens in adolescence. Therefore, a future study would reveal more differential relationships between parenting and sibling relationship for older and younger siblings when the age-spacing is wider.

Besides all these, the present study has some methodological implications regarding the possible influence of source of information on research findings. It appeared that mother-reported maternal negative discipline, but not observed maternal negative control, predicted perceived maternal hostility. This finding is understandable considering that negative discipline practices evaluated in this study included punishment and harsh parenting behaviors (e.g., smacking or slapping) whereas negative control practices were mild controlling behaviors such as criticizing and physically controlling the child during a laboratory task which was known to be recorded. However, it is quite interesting that mother-reported positive maternal discipline was not related either with perceived maternal warmth or maternal hostility. Although it might have been expected that positive maternal discipline would not be related to maternal hostility granted that they differ in valence, the lack of relationship between mother-reported positive maternal discipline and perceived maternal warmth calls for explanation. It might be that mothers gave themselves higher ratings for positive discipline practices due to social desirability bias, so it may have not been possible to detect actual relationship among these variables. Therefore, this finding demonstrates us the importance of employing observed data together with parent report. Alternatively, the reason may be that negative behaviors (including bad parenting) are more influential and more deeply processed compared to positive behaviors (including good parenting) (Baumeister, Bratslavsky, Finkenauer, \& Vohs, 2001; Gottman \& Krokoff, 1989). 
The present study has some limitations. First, although we interpreted the findings as suggesting that parental practices influence sibling relationship quality via its association with perceived parenting quality, current findings may be interpreted in the opposite direction as the study was cross-sectional. In other words, it is also possible that sibling relationship quality influences parenting practices (e.g., high levels of conflict among siblings may result in higher negative maternal control and discipline practices), which in turn affects children's perceptions of maternal warmth and hostility. Indeed, there might be a bidirectional relationship as suggested by family system perspective and demonstrated by previous research (e.g., Yu \& Gamble, 2008). Therefore, future studies may attempt to reveal the nature of relationship among parental practices, perceived parenting quality, and sibling relationship quality with a longitudinal data. Moreover, since we had a small sample size, we were not able to conduct a structural equation modelling analysis with latent variables which would yield more valid results. Future studies may overcome this limitation by recruiting larger sample and conducting more sophisticated analyses. Furthermore, we did not have any information regarding the birth order of children in the study - we had just information regarding relative birth order of siblings - so we cannot be sure whether findings regarding age related differences may be attributed to birth order or not. In addition, as mentioned earlier, the Cronbach's alpha value for mother report of negative discipline was low. Although, this may result from small number of items (see Field, 2009), future studies may use different measures to assess maternal discipline practices. Finally, we did not include fathers in this study, so future studies may also include fathers along with mothers to see whether the pattern of relations change as a function of parent gender.

In sum, the present study revealed that for both older and younger siblings, parenting practices reflect on sibling relationship and the meaning children attribute to their parents' behaviors is an important explanatory mechanism of the link between parenting practices and sibling relationship.

\section{References}

Ablow, J. C., \& Measelle, J. R. (1993). Berkeley puppet interview: Administration and scoring system manuals. Berkeley: University of California.

Aytac, B. (2013). The mother-child relationship and child behaviour: A comparison of Turkish and English families (Unpublished doctoral dissertation). University of Sussex, Brighton, UK.

Aytac, B., Pike, A., \& Bond, R. (2019). Parenting and child adjustment: A comparison of Turkish and English families. Journal of Family Studies, 25, 267-286. DOI:10.1080/13229400.2016.1248855

Baumeister, R. F., Bratslavsky, E., Finkenauer, C., \& Vohs, K. D. (2001). Bad is stronger than good. Review of General Psychology, 5, 323-370. DOI:10.1037/1089-2680.5.4.323

Boer, F., Goedhart, A., \& Treffers, P. (1992). Siblings and their parents. In F. Boer \& J. Dunn (Eds.), Children's relationships with their siblings: Developmental and clinical issues (pp. 41-54). Hillsdale, NJ: Erlbaum.

Bornstein, M. H. (2012). Cultural approaches to parenting. Parenting: Science and Practice, 12, 212-221. DOI:10.1080/15295192.2012.683359

Brody, G. H. (1998). Sibling relationship quality: Its causes and consequences. Annual Review of Psychology, 49, 1-24. DOI:10.1146/annurev.psych.49.1.1

Brody, G. H., Stoneman, Z., \& MacKinnon, C. E. (1986). Contributions of maternal child-rearing practices and play contexts to sibling interactions. Journal of Applied Developmental Psychology, 7, 225-236. DOI:10.1016/0193-3973(86)90031-6 
Brody, G. H., Stoneman, Z., \& McCoy, J. K. (1992). Parental differential treatment of siblings and sibling differences in negative emotionality. Journal of Marriage and the Family, 54, 643-651. DOI: $10.2307 / 353250$

Buhrmester, D. (1992). The developmental courses of sibling and peer relationships. In Boer, F., \& Dunn, J. (Eds.), Children's sibling relationships: Developmental and clinical issues (pp. 19-40). Erlbaum, Hillsdale, NJ.

Buist, K. L., Deković, M., \& Prinzie, P. (2013). Sibling relationship quality and psychopathology of children and adolescents: A meta-analysis. Clinical Psychology Review, 33, 97-106. DOI:10.1016/j.cpr.2012.10.007

Buist, K. L., Verhoeven, M., Hoksbergen, R., ter Laak, J., Watve, S., \& Paranjpe, A. (2017). Associations of perceived sibling and parent-child relationship quality with internalizing and externalizing problems: Comparing Indian and Dutch early adolescents. The Journal of Early Adolescence, 37, 1163-1190. DOI:10.1177/0272431616653473

Camerini, A. L., \& Schulz, P. J. (2018). Social desirability bias in child-report social well-being: Evaluation of the children's social desirability short scale using item response theory and examination of its impact on self-report family and peer relationships. Child Indicators Research, 11, 1159-1174. DOI:10.1007/s12187-017-9472-9

Chen, B. B. (2018). The relationship between Chinese mothers' parenting stress and sibling relationships: A moderated mediation model of maternal warmth and co-parenting. Early Child Development and Care, 1-9. DOI:10.1080/03004430.2018.1536048

Collins, W. A., Madsen, S., \& Susman-Stillman, A. (2002). Parenting during middle childhood. In M. Bornstein (Ed.), Handbook of parenting: Vol. 1. Children and parenting (2nd ed., pp. 73-101). Mahwah, NJ: Erlbaum.

Cui, M., Conger, R. D., Bryant, C. M., \& Elder, G. H. (2002). Parental behavior and the quality of adolescent friendships: A social-contextual perspective. Journal of Marriage and Family, 64, 676689. DOI:10.1111/j.1741-3737.2002.00676.x

Daniels, D., \& Plomin, R. (1985). Differential experience of siblings in the same family. Developmental Psychology, 21, 747-760. DOI:10.1037/0012-1649.21.5.747

Deater-Deckard, K. (2000). Parenting and child behavioral adjustment in early childhood: A quantitative genetic approach to studying family processes. Child Development, 71, 468-484. DOI:10.1111/1467-8624.00158

Deater-Deckard, K., Pylas, M., \& Petrill, S. A. (1997). The parent-child interaction system (PARCHISY). London: Institute of Psychiatry.

Derkman, M. M., Engels, R. C., Kuntsche, E., van der Vorst, H., \& Scholte, R. H. (2011). Bidirectional associations between sibling relationships and parental support during adolescence. Journal of Youth and Adolescence, 40, 490-501. DOI:10.1007/s10964-010-9576-8

Dirks, M. A., Persram, R., Recchia, H. E., \& Howe, N. (2015). Sibling relationships as sources of risk and resilience in the development and maintenance of internalizing and externalizing problems during childhood and adolescence. Clinical Psychology Review, 42, 145-155. DOI:10.1016/j.cpr.2015.07.003

Dunn, J. (2002). Sibling relationships. In P. K. Smith \& C. H. Hart (Eds.), Blackwell handbook of childhood social development (pp. 223-237). Oxford: Blackwell.

Dunn, J. F., Plomin, R., \& Daniels, D. (1986). Consistency and change in mothers' behavior toward young siblings. Child Development, 57, 348-356. DOI:10.2307/1130590

Dunn, J., \& Plomin, R. (1990). Separate lives: Why siblings are so different. New York, NY: Basic Books.

Field, A. P. (2009). Discovering statistics using SPSS (3rd ed.). London: Sage. 
Ford, L. H., \& Rubin, B. M. (1970). A social desirability questionnaire for young children. Journal of Consulting and Clinical Psychology, 35, 195-204. DOI:10.1037/h0030042

Furman, W., \& Buhrmester, D. (1985). Children's perceptions of the qualities of sibling relationships. Child Development, 56, 448-461. DOI:10.2307/1129733

Furman, W., \& Lanthier, R. (2002). Parenting siblings. In M. H. Bornstein (Ed.), Handbook of parenting (2nd ed., Vol. 1, pp. 165-188). Mahwah, NJ: Erlbaum.

Gamble, W. C., \& Yu, J. J. (2014). Young children's sibling relationship interactional types: Associations with family characteristics, parenting, and child characteristics. Early Education and Development, 25, 223-239. DOI:10.1080/10409289.2013. 788434

Garcia, M. M., Shaw, D. S., Winslow, E. B., \& Yaggi, K. E. (2000). Destructive sibling conflict and the development of conduct problems in young boys. Developmental Psychology, 36, 44-53. DOI:10.1037/0012-1649.36.1.44

Gottman, J. M., \& Krokoff, L. J. (1989). Marital interaction and satisfaction: A longitudinal view. Journal of Consulting and Clinical Psychology, 57, 47-52. DOI:10.1037/0022-006X.57.1.47

Grych, J. H., \& Fincham, F. D. (1990). Marital conflict and children's adjustment: A cognitive-contextual framework. Psychological Bulletin, 108, 267-290. DOI:10.1037/0033-2909.108.2.267

Herbert, M. (2004). Parenting across the lifespan. In M. Hoghughi, \& N. Long (Eds.), Handbook of parenting: Theory and research for practice (pp. 55-71). London: Sage Publications.

Jenkins, J., Rasbash, J., Leckie, G., Gass, K., \& Dunn, J. (2012). The role of maternal factors in sibling relationship quality: A multilevel study of multiple dyads per family. Journal of Child Psychology and Psychiatry, 53, 622-629. DOI:10. 1111/j.1469-7610.2011.02484.x

Kağıtçıbaşı, C. (1989). Family and socialization in cross-cultural perspective: A model of change. In V. Berman (Ed.), Nebraska symposium on motivation (pp. 135-200). Lincoln, NE: University of Nebraska Press.

Kidwell, J. S. (1981). Number of siblings, sibling spacing, sex, and birth order: Their effects on perceived parent-adolescent relationships. Journal of Marriage and the Family, 43, 315-332. DOI:10.2307/351383

Lansford, J. E., Malone, P. S., Dodge, K. A., Chang, L., Chaudhary, N., Tapanya, S., ... \& Deater-Deckard, K. (2010). Children's perceptions of maternal hostility as a mediator of the link between discipline and children's adjustment in four countries. International Journal of Behavioral Development, 34, 452-461. DOI:10.1177/0165025409354933

MacKinnon-Lewis, C., Starnes, R., Volling, B., \& Johnson, S. (1997). Perceptions of parenting as predictors of boys' sibling and peer relations. Developmental Psychology, 33, 1024-1031. DOI:10.1037/00121649.33.6.1024

McHale, S. M., Updegraff, K. A., Tucker, C. J., \& Crouter, A. C. (2000). Step in or stay out? Parents' roles in adolescent siblings' relationships. Journal of Marriage and Family, 62, 746-760. DOI:10.1111/j.1741-3737.2000.00746.x

Measelle, J. R., Ablow, J. C., Cowan, P. A., \& Cowan, C. P. (1998). Assessing young children's views of their academic, social, and emotional lives: An evaluation of the self-perception scales of the Berkeley Puppet Interview. Child Development, 69, 1556-1576. DOI:10.2307/1132132

Minuchin, P. (1985). Families and individual development: Provocations from the field of family therapy. Child Development, 56, 289-302. DOI:10.2307/1129720

Pike, A., Coldwell, J., \& Dunn, J. F. (2005). Sibling relationships in early/middle childhood: Links with individual adjustment. Journal of Family Psychology, 19, 523-532. DOI:10.1037/08933200.19 .4 .523 
Plomin, R., Asbury, K., \& Dunn, J. (2001). Why are children in the same family so different? Nonshared environment a decade later. The Canadian Journal of Psychiatry, 46, 225-233. DOI:10.1177/070674370104600302

Podsakoff, P. M., MacKenzie, S. B., Lee, J. Y., \& Podsakoff, N. P. (2003). Common method biases in behavioral research: a critical review of the literature and recommended remedies. Journal of Applied Psychology, 88, 879-903. DOI:10.1037/0021-9010.88.5.879

Portner, L. C., \& Riggs, S. A. (2016). Sibling relationships in emerging adulthood: Associations with parent-child relationship. Journal of Child and Family Studies, 25, 1755-1764. DOI:10.1007/s10826-015-0358-5

R Core Team. (2016). R: A language and environment for statistical computing [Computer software manual]. Vienna, Austria: R Foundadion for Statistical Computing. Retrieved from http://www.Rproject.org/

Relva, I. C., Alarcão, M., Fernandes, O. M., Carvalho, J., \& Fauchier, A. (2019). Sibling conflict and parental discipline: The mediating role of family communication in Portuguese adolescents. Child and Adolescent Social Work Journal, 36, 295-304. DOI:10.1007/s10560-019-00600-3

Richmond, M. K., Stocker, C. M., \& Rienks, S. L. (2005). Longitudinal associations between sibling relationship quality, parental differential treatment, and children's adjustment. Journal of Family Psychology, 19, 550-559. DOI:10.1037/ 0893-3200.19.4.550

Rohner, R. P. (1986). The warmth dimension: Foundations of parental acceptance-rejection theory. Thousand Oaks, CA: Sage.

Rohner, R. P., Bourque, S. L., \& Elordi, C. A. (1996). Children's perceptions of corporal punishment, caretaker acceptance, and psychological adjustment in a poor, biracial southern community. Journal of Marriage and the Family, 58, 842-852. DOI:10.2307/353974

Rohner, R.P., Kean, K.J., \& Cournoyer, D. E. (1991). Effects of corporal punishment, perceived caretaker warmth, and cultural beliefs on the psychological adjustment of children in St. Kitts, West Indies. Journal of Marriage and the Family, 53, 681-693. DOI:10.2307/352743

Rosseel, Y. (2012). Lavaan: An R package for structural equation modeling. Journal of Statistical Software, 48, 1-36. DOI:10.18637/jss.v048.i02

Sameroff, A. J., \& Haith, M. M. (1996). The five to seven year shift. Chicago: The University of Chicago Press.

Satorra, A., \& Bentler, P. M. (2001). A scaled difference chi-square test statistic for moment structure analysis. Psychometrika, 66, 507-514. DOI:10.1007/BF02296192

Seifer, R. (2005). Who should collect our data: Parents or trained observers? In D. M. Teti (Ed.), Handbook of research methods in developmental science (pp. 123-137). Malden, MA: Blackwell Publishing.

Sputa, C. L., \& Paulson, S. E. (1995). Birth order and family size: Influences on adolescents' achievement and related parenting behaviors. Psychological Reports, 76, 43-51. DOI:10.2466/pr0.1995.76.1.43

Volling, B. L., \& Elins, J. L. (1998). Family relationships and children's emotional adjustment as correlates of maternal and paternal differential treatment: A replication with toddler and preschool siblings. Child Development, 69, 1640-1656. DOI:10.1111/ j.1467-8624.1998.tb06182.x

Yu, J. J., \& Gamble, W. C. (2008). Pathways of influence: Marital relationships and their association with parenting styles and sibling relationship quality. Journal of Child and Family Studies, 17, 757-778. DOI:10.1007/s10826-008-9188-z 